\title{
Heavy Metals in Agricultural Soils of Central Ethiopia: The Contribution of Land Use Types and Organic Sources to Their Variability
}

\author{
Nigatu Alemayehu Minase ${ }^{1 *}$, Mary M. Masafu², Abule Ebro Geda ${ }^{1}$, Azage Tegegne Wolde ${ }^{1}$ \\ ${ }^{1}$ International Livestock Research Institute, Addis Ababa, Ethiopia \\ ${ }^{2}$ University of South Africa, Pretoria, South Africa \\ Email: *n.alemayehu@cgiar.org
}

Received 20 April 2016; accepted 13 June 2016; published 16 June 2016

Copyright (C) 2016 by authors and Scientific Research Publishing Inc.

This work is licensed under the Creative Commons Attribution International License (CC BY).

http://creativecommons.org/licenses/by/4.0/

(c) (i) Open Access

\section{Abstract}

In the present study, about $94 \%$ of the arable land had a phosphorus deficiency (available $P<10$ $\mathbf{m g} \cdot \mathrm{kg}^{-1}$ ). To compensate for this deficiency, high amounts of phosphorous fertilization were applied to soils to get better crop yield. In the past two decades, soil organic matter has sharply declined from $34.8 \mathrm{~g} / \mathrm{kg}$ in late $1980 \mathrm{~s}^{\prime}$ to $12.0 \mathrm{~g} / \mathrm{kg}$ in 2010 . The soil has moderate to high cation exchanging capacity (CEC) in the range of 45 - $58 \mathrm{Meq} / 100 \mathrm{gm}$. The low soil organic carbon, high CEC and high phosphorus fertilization could lead to poor heavy metal availability to plants. Nevertheless, DTPA extractable concentrations were $40.5 \mathrm{mg} / \mathrm{kg}$ for copper, $35.5 \mathrm{mg} / \mathrm{kg}$ for iron, $134 \mathrm{mg} / \mathrm{kg}$ for manganese, $2.1 \mathrm{mg} / \mathrm{kg}$ for nickel, $2.6 \mathrm{mg} / \mathrm{kg}$ for lead and $53.5 \mathrm{mg} / \mathrm{kg}$ for zinc. All the available micronutrients seem to be adequate for plant growth. In terms of toxicity, the values of $\mathrm{Cu}, \mathrm{Fe}, \mathrm{Mn}$, $\mathrm{Zn}, \mathrm{Ni}$ and $\mathrm{Pb}$ found in the present investigation were lower than those of above critical value set by the international guidelines and other researchers. Variations in heavy metal content in the soil were attributed due to differences in land use types and disparity in organic sources amongst the plant and animal composites. For better crop productivity, more organic matter should be added to the soils. The traditional nutrient cycling practices, such as manure application, allow crop residue to decay on fields, fallowing and rotational cropping has to be followed to rehabilitate the soil and buildup both macro-and micro-nutrients to their natural level.

\section{Keywords}

Phosphorous, Toxicity, Micronutrients, Organic Carbon, Nutrient Cycle

\footnotetext{
${ }^{*}$ Corresponding author.
}

How to cite this paper: Minase, N.A., Masafu, M.M., Geda, A.E. and Wolde, A.T. (2016) Heavy Metals in Agricultural Soils of Central Ethiopia: The Contribution of Land Use Types and Organic Sources to Their Variability. Open Journal of Soil Science, 6, 99-112. http://dx.doi.org/10.4236/ojss.2016.66011 


\section{Introduction}

The central Ethiopian highland is coming under increased pressure for the expansion of factories, export abattoirs, flower farms and other processing plants. These factories produce packed and semi-processed foods, tanneries and finished products like textiles, cosmetics, detergents, cement, metal and beverage products and largely congregate in $100 \mathrm{~km}$ radius of Addis Ababa, the capital of Ethiopia. This has resulted in shrinkage of the adjoining smallholders' farms that used for the production of food in the land they have used for crop cultivation and cattle grazing. The result is that at the present rate of expansion due to both urbanization and industrialization, the survival of these farmers and their farm land is at stake. Most of the cultivated area is put to food crops like teff (Eragrostis abyssinica) and wheat (Triticum aestivum) and marsh and hillsides for sheep, goats and cattle grazing. The central Ethiopian highland is also a potential cereal producing zone and it is the highest supplier of high quality crop like teff to Addis Ababa and other towns in the country. Ethiopia also needs to boost food production and this is believed to be achieved by increased crop production per unit area to meet the needs of the increasing population. In the future, increased and sustained food production will need more fertilizer amendments. Under heavy or continuous fertilization, micronutrients and other heavy metals could also be introduced into the soil [1].

In Ethiopia context, researches on heavy metal toxicity and availability to crops have been limited around few towns' along the river banks that are contaminated by factory effluents and have been used for vegetable production [2]-[7]. There has been a growing concern about food quality and safety of agricultural products obtained from such contaminated sites. It is clear that soils under repeated contamination from different pollutants eventually lose their resilience and are unable to provide good quality food products [1], but there is also a risk in productivity and quality when the level of heavy metals are below crop requirement. Though, risk of contamination from heavy metals in rural Ethiopia was minimal [1] [8], acquisition of base line data on their concentrations would be useful in future in decision making about the type of organic and/or inorganic fertilizers that could be applied [1].

Given the important role of micronutrients in plant growth and animal nutrition and the deleterious effects of heavy metal contamination in the environment, the determination of background levels of these elements is therefore an important guide to prevent physiological disorders in grazing animals as well as serving as initial threshold levels for studying micronutrient concentrations and heavy metal pollution in future [1]. The available micronutrients and heavy metals are of more importance since they constitute the nutrition pool taken up by the plants.

The naturally occurring background levels of heavy metals in uncontaminated soils usually occur in trace amounts related to the biogeochemistry of the parent materials [9]. Heavy metal content and distribution in soils are influenced by several factors including organic matter content, types of land management, particle-size distribution, parent material, drainage, soil age, vegetation and aerosol input [10] [11]. In the present study we would like to streamline the type of specific organic sources and land use types that could have influenced the content and distribution of heavy metals.

In the current study six heavy metals ( $\mathrm{Cu}, \mathrm{Fe}, \mathrm{Mn}, \mathrm{Ni}, \mathrm{Pb}$ and $\mathrm{Zn}$ ) were analyzed for their level of heavy metal concentration in smallholders' farms in Central Ethiopia. $\mathrm{Fe}$ and $\mathrm{Cu}$ are very important and mobile elements which have been widely studied globally, $\mathrm{Ni}$ and $\mathrm{Zn}$ are mobile in the soil are essential for plant growth, while $\mathrm{Pb}$ (although a relatively immobile metal) is considered a very serious environmental contaminant [12]. In the light of all the above, soil samples were collected and analyzed to emphasis the impact of applying different organic sources in to soil and explain the role of land management in heavy metal load in the soil. The spilling of industrial effluent into neighborhood crop farms through water flows and flooding were highlighted to indicate the future shadow of industrial development in rural environment. It will be obvious that with increasing urbanization and industrialization in Central Ethiopian highland the future environmental issue will be on land utilization of sludge and municipal waste management. Therefore, determination of heavy metal concentration is an important guide to protect the public health hazards as well as serve as initial threshold levels for studying heavy metal pollution in the future.

The specific purpose of this study was to:

- Determine the heavy metal concentration in agricultural soils of the study area.

- Compute the variation of heavy metal in different land use at the soil depths of 0 to $15 \mathrm{~cm}$ and 15 to $30 \mathrm{~cm}$.

- Compare heavy metal variation under the influence of different organic sources at the soil depths of 0 to 15 $\mathrm{cm}$ and 15 to $30 \mathrm{~cm}$. 


\section{Materials and Methods}

\subsection{Location of Sites}

Ada district lies between longitudes $38^{\circ} 51^{\prime}$ to $39^{\circ} 04^{\prime} \mathrm{E}$ and latitudes $8^{\circ} 46^{\prime}$ to $8^{\circ} 59^{\prime} \mathrm{N}$ covering an area of $1750 \mathrm{~km}^{2}$ east of Addis Ababa. Most of the land (90\%) was plain highlands ranging between 1600 to 2000 meters above sea level. The district is characterized by sub-tropical climate and receives $860 \mathrm{~mm}$ rain per annum [13]. Mean annual temperatures ranged from about $8^{\circ} \mathrm{C}$ to $28^{\circ} \mathrm{C}$. Black clay vertisol soil was the dominant soil type. Ada district is became an industrial hot spot due to its proximity to Addis Ababa and situated on the main road that connects Ethiopia to sea port of Djibouti as well as serve as a trade corridor to agricultural commodity market between Central, Southern and Eastern Ethiopia (see Figure 1).

\subsection{Soil Sample Categories}

In the study area 15 soil samples sites were taken at the depth of 0 to $15 \mathrm{~cm}$ and 15 to $30 \mathrm{~cm}$. Four subsamples were taken from each sample site. Subsamples of each site were mixed and pooled in one bag. The sample sites were grouped in two categories by [14] according to (a) land use and management (b) sources of organic matter (see Table 1).

The sites were also categorized according to their land use as follows (a) Sites with chemical disposal effluents reach farms through water flow and folds from factory outlets such as detergents, steel, plastic bags, and food processing plants, Number of sites or $\mathrm{N}=4$; (b) Grazing land these are communal grazing land allocated for livestock grazing only, $\mathrm{N}=2$; (c) Croplands that were solely used for crop cultivation for more than 3 decades, $\mathrm{N}=7$; (d) Undisturbed land that was free of human and animal interference for more than 3 decades, such as church and research compounds and areas enclosed for conservation and biodiversity, $\mathrm{N}=2$.

The other grouping of the sample sites was the three classes of organic sources such as: (a) Animal debris from slaughter house waste disposal places sites, $N=5$; (b) Plant debris which included decayed crop residues and

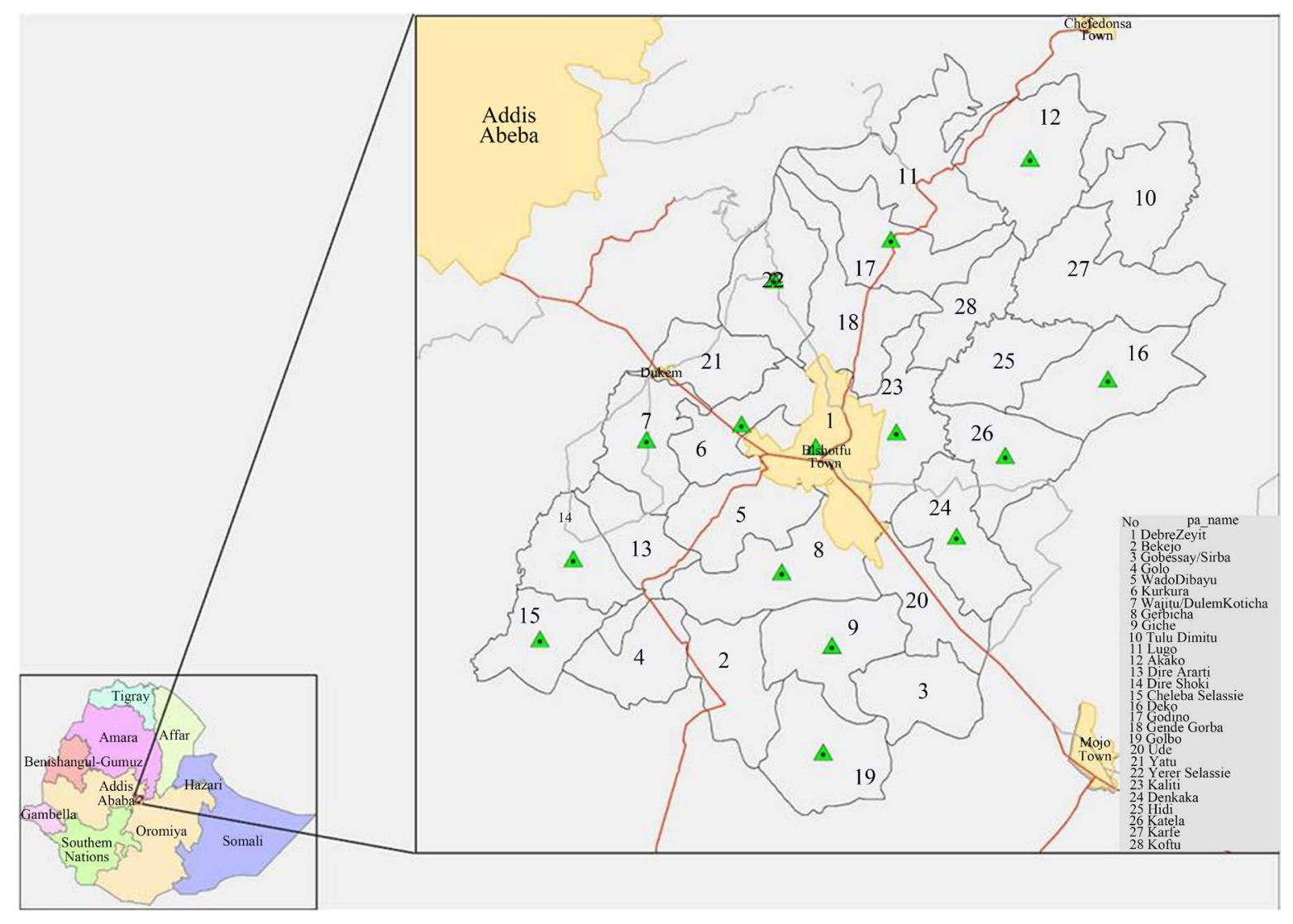

Figure 1. Location of the study area and sample sites denoted with a symbol of green triangle. 
Table 1. Sample sites and their characteristics.

\begin{tabular}{cccc}
\hline $\begin{array}{c}\text { Case } \\
\text { number }\end{array}$ & Sample site & Land use & $\begin{array}{c}\text { Source of } \\
\text { organic manure }\end{array}$ \\
\hline 1 & DZ research center & Uncultivated & None \\
2 & Private commercial Farm & Cropland & Animal \\
3 & Crop rotation plot & Cropland & Plant \\
4 & Minimum tillage & Cropland & Plant \\
5 & Farmyard manure plot & Cropland & Animal \\
6 & Compost plot & Cropland & Plant \\
7 & Recycling residue & Cropland & Plant \\
8 & Communal grazing & Grazing & Animal \\
9 & Fenced & Uncultivated & None \\
10 & Mechanized farming & Cropland & None \\
11 & Effluent contaminated & Chemical disposal & None \\
12 & Effluent contaminated & Chemical disposal & None \\
13 & Effluent contaminated & Chemical disposal & None \\
14 & Abattoir waste disposal & Chemical disposal & Animal \\
15 & Swampy disposal site & Grazing & Animal \\
\hline & & & \\
\hline & & & \\
\hline
\end{tabular}

compost from crop rotation and non-organic sources, $\mathrm{N}=4$; (c) no external plant and animal organic additions, $\mathrm{N}=6$. The last category was helpful in the analysis of heavy metal loads in soils and their mobility due to natural sediments and soil contents.

\subsection{Sampling and Chemical Analysis}

Soil samples were collected purposely to describe the different land management practices and different organic sources such as degradation, area enclosure, crop history, tillage type, and levels of fertilization, residues left in the field and presence or absences of compost or manure applications. Samples were taken at the depths of 0 to $15 \mathrm{~cm}$ and at 15 to $30 \mathrm{~cm}$ with four subsamples at each composite site. Thus, a composite sample was made from four pooled subsamples. The four subsamples at each site were pooled for homogeneity and stored in a plastic bag and transported to Debrezeit Research Centre for soil chemical analysis in the Soil Laboratory within two hours of collection.

The pooled samples were air dried at ambient temperature and crushed to pass through a 2 mm stainless sieve. Then portions of pooled samples (about $50 \mathrm{~cm}$ ) were ground to pass through a $0.149 \mathrm{~mm}$ sieve and stored in plastic bags prior to the chemical analysis. The pooled samples were analyzed for the following properties: $\mathrm{pH}$, CEC, soil organic matter (SOM), available $\mathrm{P}, \mathrm{Fe}, \mathrm{Mn}, \mathrm{Ni}, \mathrm{Cu}, \mathrm{Zn}$ and $\mathrm{Pb}$. All the micro-nutrients were determined by DTPA extract through Atomic Absorption Spectrometer [15]. Soil pH was determined by a pH meter with a soil/water ratio of $1: 2.5$. Available $\mathrm{P}$ was extracted by shaking $1.5 \mathrm{gm}$ of soil sample for 30 minutes at $20^{\circ} \mathrm{C}$ in $100 \mathrm{~mL}$ of a $42 \% \mathrm{NaHCO}_{3}$ solution at $\mathrm{pH} 8.5$ according to [16]. The organic content in the soil was determined based on the method from [17]. CEC was determined using ammonia distillation [18]. Exchangeable bases such as Ca were measured using $1 \mathrm{~N}$ ammonium acetate per unit of meq/100 gm of soil.

\subsection{Statistical Analysis}

Statistical analysis and graphs were performed using [19]. General linear model (GLM) was used to compare the mean difference of different treatments. Correlation (r) and analysis of variance (ANOVA) were also calculated. The univariate analysis of variance was used to determine the mean, standard deviation and significant differ- 
ences of heavy metal concentrations in the soil.

Cluster analysis was used in the grouping of different sample sites with various levels of heavy metal content in the soil. Cluster analysis or clustering is the task of assigning a set of objects into groups (clusters) so that the objects in the same cluster are more similar to each other than to those in other clusters [20]. At different distances, different clusters form a dendrogram or hierarchical clustering [21]. In the current study euclidean distance, the most commonly chosen type of distance was used [20]. It is preferred for the geometric distance in the multidimensional space. It is computed as:

$$
\text { distance }(x, y)=\left\{\sum_{i}\left(X_{i}-Y_{i}\right)^{2}\right\}^{1 / 2} \text {. }
$$

In a dendrogram, the $\mathrm{X}$-axis marks the distance at which the clusters merge, while the objects are placed along the Y-axis so that the clusters don't mix. Popular choices are known as single-linkage clustering that use minimum distance between objects [20].

\section{Results and Discussions}

The concentrations of heavy metals in the soil and their impacts on ecosystems can be influenced by many factors such as parent material, climate and anthropogenic activities ([12]. Heavy metals may be added to soils in chemical fertilizers and pesticides, soil amendments (e.g. Lime and gypsum) or organic fertilizers [22]. Cluster analysis for heavy metals assists in tracing the origins of elevated levels of heavy metals in soil. This paper explains the origin and sources of heavy metals in the study area, the contribution of different organic sources to heavy metal loads, and describes the relationship of heavy metals to land use type.

\subsection{Origins of Trace Elements in Soils of the Study Area}

The important consideration in the heavy metal identification in soils was to determine the original sources such as natural weathering, industrial processing, use of metal components in commercial processes, aerial deposition of smelting materials, leaching from garbage and solid waste dumps, the application of animal products, or some other sources [23].

Heavy metals in smallholder agriculture were mostly related to the addition of organic and inorganic nutrients to the soil. Most of the materials were added to soil for agricultural purposes such as manure, lime and other inorganic fertilizers have low trace element levels and when they were applied at normal rates and they did not affect overall concentrations of trace elements in soil. However, when they were applied at a higher rate they raised the concentration of trace elements in the soil. Other sources of inputs that increased the concentration of heavy metals in soil, included herbicides, fungicides, irrigation water, biosolid application, dredged materials, fly ash and municipal composts [24].

In the current study, the cluster analysis sample sites were classified into seven groups, after assigning average weight based on Eculdian distance measurement for all variables [20]. It was found that major sources of heavy metals were ordered in their importance as follows in sample sites 13 - 15, 9 and 3. Site 13 represents steal rolling effluent discharge, site 14 was a place for municipal abattoir disposal where animal waste was disposed, site 15 located in swampy area where waste and dead animals' bodies were disposed, site 9 is a location fenced off from animal and human entrance and site 3 was a farm plot where crop rotation was practiced for a long period by rotating pulses with cereals. The result of the cluster analysis showed that the three major factors that contributed to heavy metal stock in soils in the study area (contributed for more than $60 \%$ variation) were anthropogenic factors such as the flow of factory effluents to farms, addition of organic products and natural factors such as soil sediments as shown in Figure 2.

The physical and chemical characteristics of heavy metal concentrations in topsoil of the study area are shown in Table 2. The pH of the topsoil was between 6.38 and 8.08 (average 7.00) at both soil depths. The soils had a normal $\mathrm{pH}$ but about $56 \%$ of samples had $\mathrm{pH}>7.0$. Soil scientists have reported that the $\mathrm{pH}$ was an essential factor that influenced the cation mobility and regulated the solubility of heavy metals in the soil as most of the metals tend to be available to plants in acidic pH. [25]. Higher soil $\mathrm{pH}$ is not favorable for the transfer of heavy metals from the soil to plants [26]. From Table 2, it is possible to argue that at both soil depths heavy metals in the top soil are available to plants due to normality of the $\mathrm{pH}$. CEC refers to the preservation and supply of soil fertilizer and buffering capacity. The mean of the soil CEC in current study was $46 \pm 12.4$ 


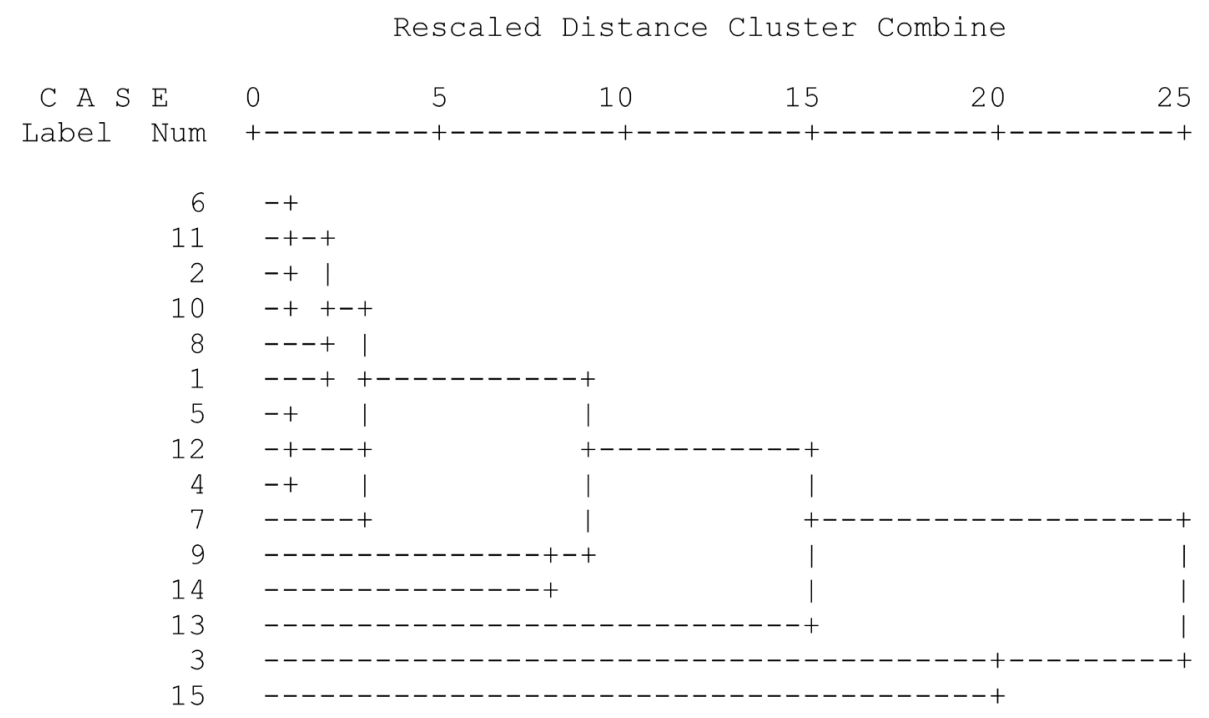

Figure 2. A dendrogram showing hierarchical cluster analysis.

Table 2. Aggregated statistical value of important soil variables.

\begin{tabular}{cccccc}
\hline Variables with soil depth & Mean & SD & Minimum & Maximum \\
\hline Soil carbon \% & $0-15 \mathrm{~cm}$ & 1.40 & 1.03 & 0.07 & 3.90 \\
& $15-30 \mathrm{~cm}$ & 0.99 & 0.73 & 0.07 & 2.48 \\
Cation exchange & $0-15 \mathrm{~cm}$ & 44.95 & 14.22 & 14.80 & 58.80 \\
Meq/100gm & $15-30 \mathrm{~cm}$ & 46.88 & 10.58 & 27.80 & 58.80 \\
Electrical cond. & $0-15 \mathrm{~cm}$ & 93.62 & 100.12 & 19.23 & 435.00 \\
Mic. Siem & $15-30 \mathrm{~cm}$ & 132.06 & 135.83 & 19.24 & 496.00 \\
PH & $0-15 \mathrm{~cm}$ & 7.00 & 0.36 & 6.47 & 8.08 \\
& $15-30 \mathrm{~cm}$ & 7.00 & 0.37 & 6.38 & 7.97 \\
Available P (ppm) & $0-15 \mathrm{~cm}$ & 31.94 & 33.54 & 7.92 & 137.19 \\
& $15-30 \mathrm{~cm}$ & 37.17 & 66.87 & 3.75 & 271.88 \\
Ca & $0-15 \mathrm{~cm}$ & 21.54 & 8.37 & 7.05 & 36.33 \\
Meq/100gm & $15-30 \mathrm{~cm}$ & 21.87 & 8.31 & 9.48 & 37.29 \\
\hline
\end{tabular}

$\mathrm{mmol} \cdot \mathrm{kg}^{-1}$. The range was between 45.00 and $58.80 \mathrm{mmol} \cdot \mathrm{kg}^{-1}$, implying that the soils had higher CEC [27] with moderate capacity to retain and maintain soil fertility. Soils SOM (Soil Organic Matter) was $12.00 \mathrm{~g} / \mathrm{kg}$ when this value compared with the findings reported by [28] of $34.8 \mathrm{~g} / \mathrm{kg}$ in the identical site, SOM has sharply decline in the past two decades. For all soils $\mathrm{pH}$, available $\mathrm{P}$, Ca and CEC generally remained the same with both soil depths while organic carbon and EC had an opposite trend (Table 2). This is consistent with finding for some Vertisols of Bale Mountain [1].

The decline in soil carbon over the past two decades was attributed due to decrease in soil nutrient cycling under mixed crop-livestock production systems. This has happened for the reason that straw and crop stalks are used as animal feed, for construction material and off-farm sales. In addition, dung was used as fuel for household energy consumption and sold for income generation instead of being used as organic fertilizer [27]. In general there is a net export of nutrients from farm soil that is imbalanced with import.

In the present study about $94 \%$ of the arable land had a phosphorus deficiency (available $\mathrm{P}<10 \mathrm{mg} \cdot \mathrm{kg}^{-1}$ ), and 
$67 \%$ of that had a severe phosphorus deficiency (available $\mathrm{P}<5 \mathrm{mg} \cdot \mathrm{kg}^{-1}$ ) [29]. Therefore, large amounts of phosphorus fertilizer inputs were the primary means to gain higher yields in agriculture in Ethiopia [27]. To compensate for the deficiency high amounts of phosphorous were applied to soils to get better crop yield. However, excessive and inappropriate use of phosphorus fertilizer would inevitably lead to chemical and physical changes in soils [26] [30]. On top of this the characteristics of moderate CEC and low SOC content in the study area could made unfavorable for heavy metal sorption [12]. As a result the availability of heavy metals to plants nutrition would be in critical condition possibility due to Phosphorous over fertilization and lower soil organic carbon content [31] has reported that grain and straw yield of teff crop in central Ethiopia highland has quadrupled when supplemented by micro-nutrients such as $\mathrm{Zn}, \mathrm{Cu}, \mathrm{Mg}$ and $\mathrm{S}$.

DTPA extractable critical concentrations for plant growth were 0.12 to $0.25 \mathrm{mg} / \mathrm{kg}$ for copper, 2.5 to 5.0 $\mathrm{mg} / \mathrm{kg}$ for iron, 1.0 to $5.0 \mathrm{mg} / \mathrm{kg}$ for manganese and 0.5 to $1.0 \mathrm{mg} / \mathrm{kg}$ zinc [1]. DTPA extracted micro-nutrients of this study were $40.5 \mathrm{mg} / \mathrm{kg}$ for copper, $35.5 \mathrm{mg} / \mathrm{kg}$ for iron, $134 \mathrm{mg} / \mathrm{kg}$ for manganese, $2.1 \mathrm{mg} / \mathrm{kg}$ for nickel, $2.6 \mathrm{mg} / \mathrm{kg}$ for lead and $53.5 \mathrm{mg} / \mathrm{kg}$ for zinc. All the available micronutrients concentration for the central Ethiopian highland soils seems to be adequate for plant growth (Table 3). In terms of toxicity, the values of $\mathrm{Cu}, \mathrm{Fe}$, $\mathrm{Mn}, \mathrm{Zn}, \mathrm{Ni}$ and $\mathrm{Pb}$ found in the present investigation were lower than those of above critical value set by the international guidelines and other researchers (Table 3).

\subsection{Relationship between Heavy Metals and Different Organic Sources}

In physical terms organic matter improves the stability of soil aggregates resulting in better aeration of the soil and better water retention. It also improves the hydraulic conductivity as a result of the increasing percentage of soil macro-pores [32]. Thus, it contributes to the increase in adsorption.

Fulvic acids are organic substances found in organic compounds in soils, which predominantly have lower molecular weights than humic acids, usually not more than 5,000 gm mol${ }^{-1}$, and are often called dissolved organic carbon (DOC) [33]. These low molecular weight materials easily dissolve in aqueous media in the range of $\mathrm{pH}$ normally found in soils and that they can be taken up by plant roots directly along with the metals that they have bound [34] [35].

In the current study the relationship between organic sources and trace minerals was identified as substantial. It was found that $\mathrm{Cu}, \mathrm{Zn}$ and $\mathrm{Ni}$ have significant differences $(\mathrm{P}<0.05)$ between different organic sources at 0 to $15 \mathrm{~cm}$ soil depth. In case of $\mathrm{Zn}$ there was a significant difference observed between animal sources $(0.86 \mathrm{ppm} \pm$ 0.58 ) and the other two organic sources (no fertilizer addition $0.44 \mathrm{ppm} \pm 0.15$ and plant sources $0.42 \mathrm{ppm} \pm$ 0.17). It showed that animal source was the major contributor to $\mathrm{Zn}$ load at 0 to $15 \mathrm{~cm}$ soil depth. Ni was higher for non-organic sources as shown in Table 4. For $\mathrm{Cu}$ there was no significant difference between animal sources $(0.50 \mathrm{ppm} \pm 0.43)$ and no fertilizer added $(0.51 \mathrm{ppm} \pm 0.22)$. There was a significant difference in Cu content between plant sources $(0.18 \mathrm{ppm} \pm 0.09)$; and animal sources and no fertilizer addition at 0 to $15 \mathrm{~cm}$ depth, which indicated that the contribution of plant debris to $\mathrm{Cu}$ stock in the soil was low. There was no significant difference $(\mathrm{P}<0.05)$ for $\mathrm{Pb}, \mathrm{Mn}$ and $\mathrm{Fe}$ at 0 to $15 \mathrm{~cm}$ soil depth. In general at a soil depth of $0-15 \mathrm{~cm}$

\begin{tabular}{|c|c|c|c|c|}
\hline Element & $\begin{array}{c}\text { Bulbula } \\
\text { (Addis Ababa) }\end{array}$ & $\begin{array}{c}\text { Kera } \\
\text { (Addis Ababa) }\end{array}$ & Current study area & Guidelines for metal above standard level \\
\hline & Soil (total) & Soil (total) & Soil (total) & Soil (total) \\
\hline & $\left(\mathrm{mg} \cdot \mathrm{kg}^{-1}\right)$ & $\left(\mathrm{mg} \cdot \mathrm{kg}^{-1}\right)$ & $\left(\mathrm{mg} \cdot \mathrm{kg}^{-1}\right)$ & $\left(m g \cdot \mathrm{kg}^{-1}\right)$ \\
\hline $\mathrm{Cu}$ & 38.96 & 55 & 40.5 & 100 \\
\hline $\mathrm{Fe}$ & 163.86 & 79.7 & 35.5 & 50000 \\
\hline $\mathrm{Mn}$ & 6587 & 3598 & 134.0 & 2000 \\
\hline $\mathrm{Ni}$ & 74.13 & 115 & 2.1 & 50 \\
\hline $\mathrm{Pb}$ & 46.47 & 110 & 2.6 & 100 \\
\hline $\mathrm{Zn}$ & 2985.5 & 263 & 53.5 & 300 \\
\hline
\end{tabular}

Source: For Bulbula and Kera [2] [12] and for Guidelines [33] 
the concentration of all heavy metals was higher for those organic sources from animal origin than for those from plant origin (see Figure 3 and Table 4).

The heavy metal concentration was significantly influenced by the addition of fertilizers from different organic sources, especially for Fe and Zn at 15 to $30 \mathrm{~cm}$ soil depth. The $\mathrm{F}$ test at $\mathrm{P}<0.05$ based on the linearity of independent variables for paired comparisons among the estimated marginal means of Fe and Zn showed a

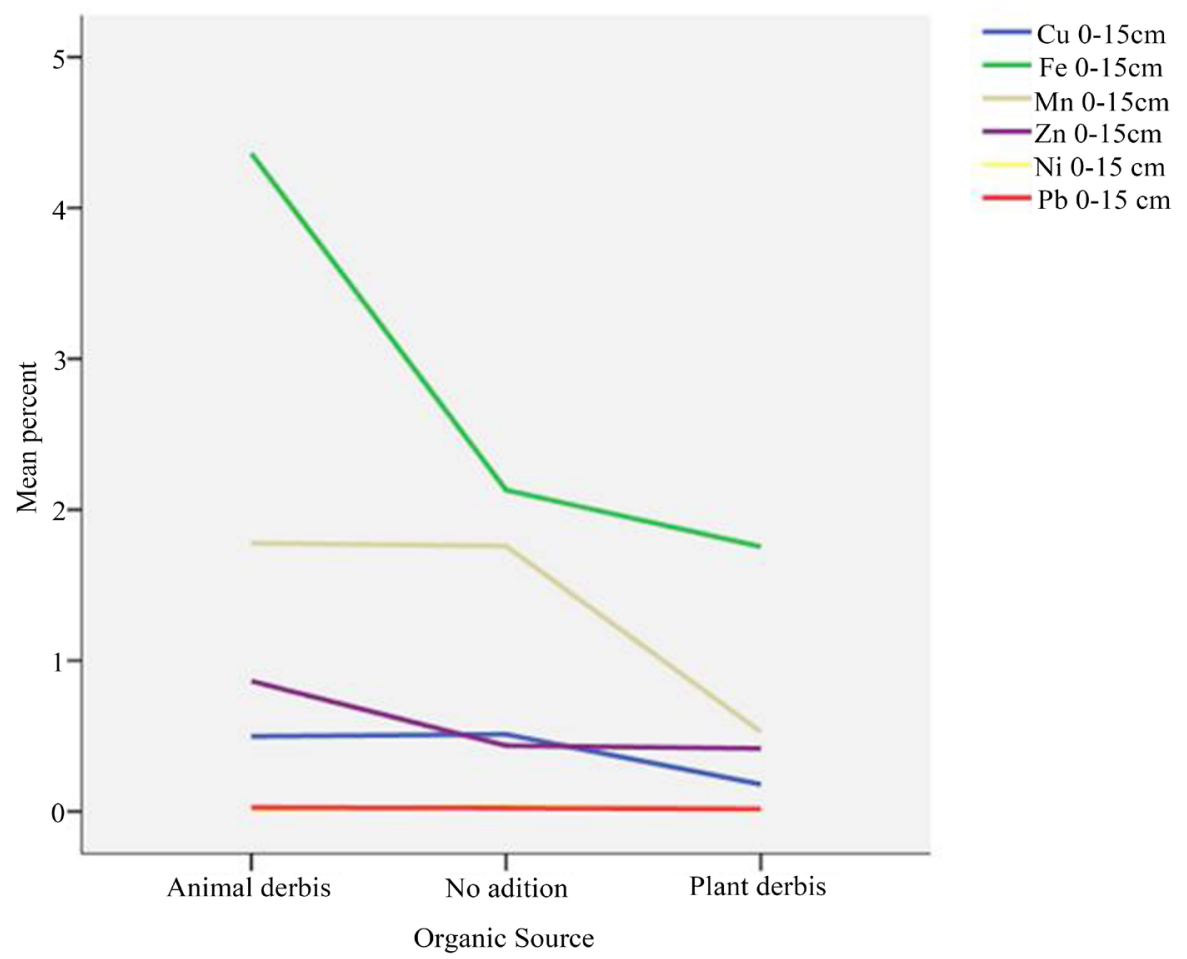

Figure 3. The mean percent of heavy metals by organic sources at $0-15 \mathrm{~cm}$ soil depth.

Table 4. Heavy metal concentration by organic sources.

\begin{tabular}{ccccc}
\hline \multicolumn{3}{c}{ Organic source } \\
\hline Element & Soil depth & Animal source $(\mathrm{N}=5)$ & No organic fertilizer $(\mathrm{N}=6)$ & Plant source $(\mathrm{N}=4)$ \\
$\mathrm{Cu}$ & $0-15 \mathrm{~cm}$ & $0.50 \pm 0.43$ & $0.51 \pm 0.22$ & $0.18 \pm 0.09$ \\
& $15-30 \mathrm{~cm}$ & $0.50 \pm 0.51$ & $0.46 \pm 0.28$ & $0.15 \pm 0.09$ \\
$\mathrm{Fe}$ & $0-15 \mathrm{~cm}$ & $4.36 \pm 4.32$ & $2.13 \pm 1.37$ & $1.76 \pm 2.16$ \\
& $15-30 \mathrm{~cm}$ & $8.88 \pm 8.95$ & $2.41 \pm 1.76$ & $1.54 \pm 2.32$ \\
$\mathrm{Mn}$ & $0-15 \mathrm{~cm}$ & $1.78 \pm 2.71$ & $1.76 \pm 0.43$ & $0.53 \pm 0.35$ \\
& $15-30 \mathrm{~cm}$ & $1.60 \pm 2.01$ & $1.46 \pm 0.42$ & $0.48 \pm 0.36$ \\
$\mathrm{Zn}$ & $0.15 \mathrm{~cm}$ & $0.86 \pm 0.58$ & $0.44 \pm 0.15$ & $0.42 \pm 0.17$ \\
& $15-30 \mathrm{~cm}$ & $0.75 \pm 0.51$ & $0.04 \pm 0.01$ & $0.38 \pm 0.19$ \\
$\mathrm{Ni}$ & $0-15 \mathrm{~cm}$ & $0.01 \pm 0.01$ & $0.04 \pm 0.01$ & $0.01 \pm 0.01$ \\
& $15-30 \mathrm{~cm}$ & $0.02 \pm 0.01$ & $0.03 \pm 0.01$ & $0.01 \pm 0.00$ \\
$\mathrm{~Pb}$ & $0.15 \mathrm{~cm}$ & $0.03 \pm 0.01$ & $0.02 \pm 0.01$ & $0.01 \pm 0.01$ \\
& $15-30 \mathrm{~cm}$ & $0.02 \pm 0.01$ & $0.03 \pm 0.01$ & $0.02 \pm 0.01$ \\
\hline
\end{tabular}


significant difference in the addition of fertilizer from organic sources into the soil. The mean Fe concentration at 15 to $30 \mathrm{~cm}$ depth was $8.88 \mathrm{ppm} \pm 8.95$ for animal sources as compared from plant sources of 1.54 p.m. \pm 2.32 and no-fertilizer was $2.41 \mathrm{ppm} \pm 1.76$.

At the depth of 15 to $30 \mathrm{~cm}$, the concentration of Zn was higher for Animal sources (0.86 ppm \pm 0.58 ) medium for no fertilizer $(0.44 \mathrm{ppm} \pm 0.15)$ and lower for plant sources $(0.42 \mathrm{ppm} \pm 0.17)$. The result showed at 15 - $30 \mathrm{~cm}$ soil depth implied that animal waste products had a significant impact on the concentration of $\mathrm{Fe}$ and $\mathrm{Zn}$ in the subsoil. Other trace minerals $\mathrm{Cu}, \mathrm{Mn}, \mathrm{Ni}$ and $\mathrm{Pb}$ did not show any significant difference for different organic sources at 15 to $30 \mathrm{~cm}$ depth, particularly the insignificance of $\mathrm{Pb}$ could be associated with poor mobility potential of $\mathrm{Pb}$ in the soil [36] [37].

In general animal source contribution to heavy metal concentration was higher for Zn and Fe at both 0 to 15 $\mathrm{cm}$ and 15 to $30 \mathrm{~cm}$ soil depth as shown in Table 4 and Figure 3, but still their level of concentration was below the environmental hazard standard this is mainly attributed due to high organic carbon in animal sources than others.

In the present study animal sources enhanced heavy metal mobility down the soil profile (except for $\mathrm{Pb}$ ) when compared with two other sources, mainly due to relatively high organic carbon content from animal sources ( $1.96 \%$ organic carbon (OC) \pm 1.32 at 0 to $15 \mathrm{~cm}$ depth and $1.57 \%$ OC \pm 0.73 at 15 to $30 \mathrm{~cm}$ depth). Carbon content of plant sources was $1.20 \% \mathrm{OC} \pm 0.92$ at 0 to $15 \mathrm{~cm}$ depth and $0.88 \% \mathrm{OC} \pm 0.42$ at 15 to $30 \mathrm{~cm}$, and that of no-fertilizer was $1.06 \%$ OC \pm 0.76 at 0 to $15 \mathrm{~cm}$ depth and $0.57 \%$ OC \pm 0.64 at 15 to $30 \mathrm{~cm}$. These findings were in agreement with the findings of [33], who reported that the addition of high carbon sewerage sludge enhanced trace elements mobility down the soil profile in Greece and United Kingdom. Other study found that well decomposed, low molecular weight organic compounds may facilitate the transport of heavy metals into the soil profile [38]. Soil scientists tested this hypothesis and found that some DOC had an effect, but not with a very substantial contribution [39]. Although the present concentration level of heavy metal was not a serious problem in the study area, but certain soil parameters should be studied before organic compounds are applied into the soil to avoid any risks of future groundwater contamination. In general at a soil depth of 15 - $30 \mathrm{~cm}$ the concentration of all heavy metals was higher for those organic sources from animal origin than for those from plant origin (see Figure 4).

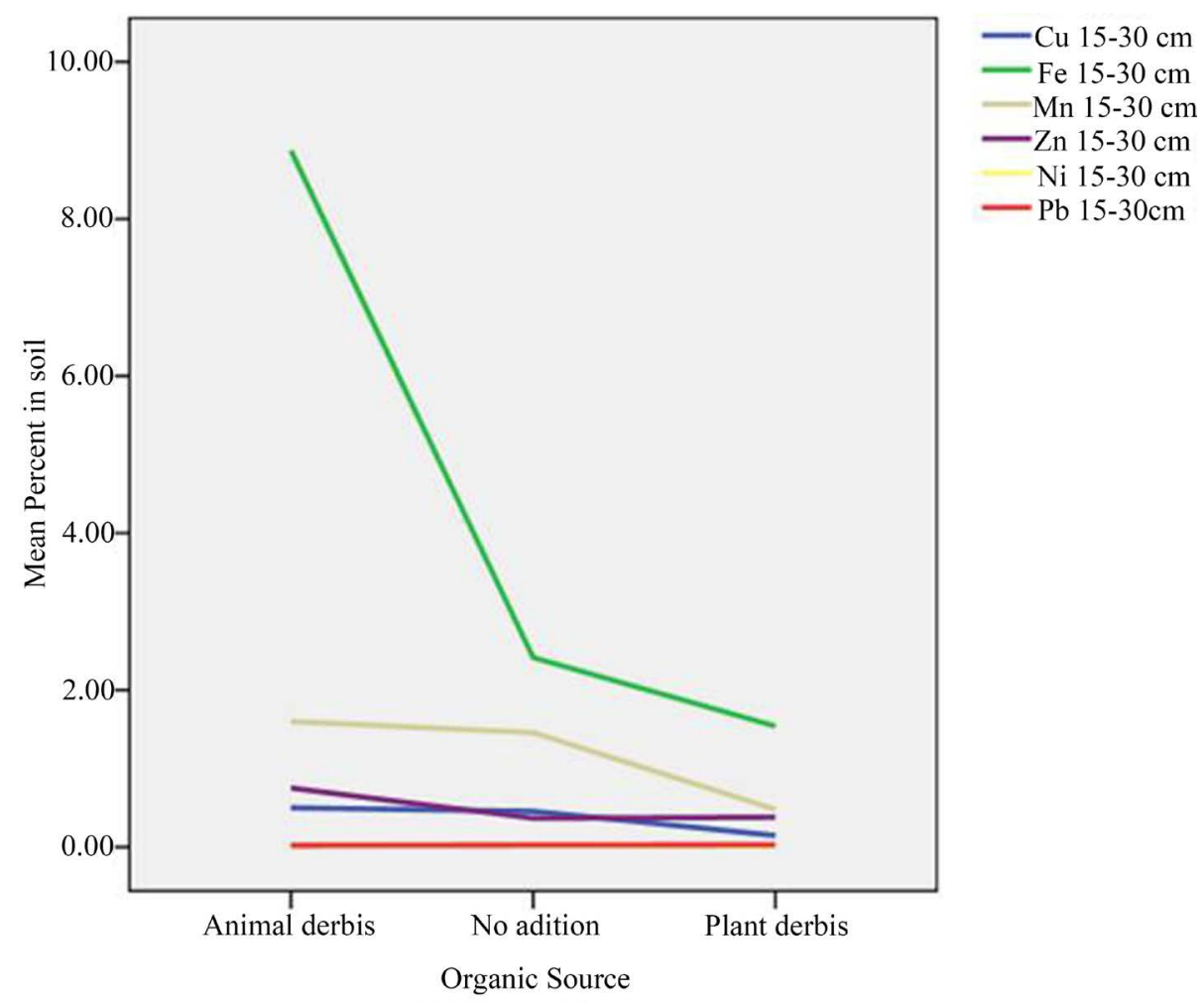

Figure 4. The mean percent of heavy metals by organic sources at $15-30 \mathrm{~cm}$ soil depth. 


\subsection{Heavy Metal Concentration and Land Use Type}

Available heavy metals were the fractions of the total concentration of these metals in the soil, which was soluble in the soil solution or easily exchangeable from the soil surfaces. The availability of metals in soils depended on their forms and concentrations in the parent material and their input through commercial fertilizer, manure and municipal wastes, factory effluents and aerial deposition. In the absence of pollutants, natural levels of metals in soils were dictated by the types of elements in rocks, weathering rates, organic matter content, soil texture and soil depth [1]. It was also being affected by leaching processes, adsorption and desorption from the solid phase. Thus land use or management of a certain area has impacted on the heavy metal concentration of that specific locality [11] [40].

In the current study relationship of heavy metal concentration and land use type gave a different picture for various land use categories as shown in Table 5 and Figure 4. There was a significant difference $(\mathrm{P}<0.05)$ for $\mathrm{Cu}, \mathrm{Fe}, \mathrm{Mn}, \mathrm{Zn}$ and $\mathrm{Ni}$ at 0 to $15 \mathrm{~cm}$ soil depth but no significant differences for $\mathrm{Pb}$. $\mathrm{Cu}$ had a high significant difference between the sites for chemical discharges $(0.83 \mathrm{ppm} \pm 0.27$ ), cropland $0.28 \mathrm{ppm} \pm 0.14$, grazing land $0.18 \mathrm{ppm} \pm 0.14$ and Undisturbed site $0.34 \mathrm{ppm} \pm 0.12$. This implied that $\mathrm{Cu}$ was one of the factory effluents discharged to farmers' fields that could pose a threat to future human and livestock health.

At the depth of 0 to $15 \mathrm{~cm}$ grazing land had a significant level of Fe (7.70 ppm \pm 3.95$)$ compared with other ecological groups (Cropland $0.82 \mathrm{ppm} \pm 0.81$, chemical discharged sites $3.80 \mathrm{ppm} \pm 2.26$ and undisturbed sites $2.60 \mathrm{ppm} \pm 1.86$ ). The difference in Fe concentration could be due to livestock manure and urine on grazing land. Cropland had the lowest iron concentration of 0 to $15 \mathrm{~cm}$ depth, indicated that crops with high iron content like Teff [41] might have drained a significant amount of iron from the soil system, which mean that there was a need to compensate the soil for iron lost through nutrient absorption. High concentrations of Zn (1.26 ppm \pm $0.90)$ and $\mathrm{Mn}(3.73 \mathrm{ppm} \pm 3.99)$ at 0 to $15 \mathrm{~cm}$ in undisturbed sites demonstrated that these two trace elements were depleted their concentration over time due to human anthropogenic factors.

There was a significant difference in Ni concentration $(0.03 \mathrm{ppm} \pm 0.02)$ at 0 to $15 \mathrm{~cm}$ between chemical discharged sites and others land use groups which illustrated that effluents from factories with high $\mathrm{Ni}$ concentration could be a threat to farms situated near factories. In general chemical load by Ni and Cu at 0 to 15 $\mathrm{cm}$ depth was a threat, but still the hazard level is far below the environmental standard limit. In general farm sites near to chemical discharged areas have higher heavy chemical loads as compared to other site categories (see Figure 5 and Table 4).

Table 5. Heavy metal concentration in the soil by land use and soil depth.

\begin{tabular}{|c|c|c|c|c|c|}
\hline \multicolumn{6}{|c|}{ An ecological history } \\
\hline Element & Soil depth & $\begin{array}{c}\text { Chemical discharged } \\
\text { sites }(\mathrm{N}=4)\end{array}$ & $\begin{array}{c}\text { Crop } \\
\text { land }(\mathrm{N}=7)\end{array}$ & $\begin{array}{c}\text { Grazing } \\
\text { land }(\mathrm{N}=2)\end{array}$ & $\begin{array}{l}\text { Undisturbed } \\
\text { sites }(\mathrm{N}=2)\end{array}$ \\
\hline \multirow{2}{*}{$\mathrm{Cu}$} & $0-15 \mathrm{~cm}$ & $0.83 \pm 0.27$ & $0.28 \pm 0.14$ & $0.18 \pm 0.14$ & $0.34 \pm 0.12$ \\
\hline & $15-30 \mathrm{~cm}$ & $0.79 \pm 0.36$ & $0.17 \pm 0.11$ & $0.18 \pm 0.04$ & $0.58 \pm 0.42$ \\
\hline \multirow{2}{*}{$\mathrm{Fe}$} & $0-15 \mathrm{~cm}$ & $3.8 \pm 2.26$ & $0.82 \pm 0.81$ & $7.70 \pm 3.95$ & $2.60 \pm 1.86$ \\
\hline & $15-30 \mathrm{~cm}$ & $6.63 \pm 6.76$ & $0.77 \pm 0.92$ & $6.30 \pm 1.85$ & $10.3 \pm 13.22$ \\
\hline \multirow{2}{*}{ Mn } & $0-15 \mathrm{~cm}$ & $1.70 \pm 0.55$ & $0.97 \pm 0.72$ & $0.26 \pm 0.26$ & $3.73 \pm 3.99$ \\
\hline & $15-30 \mathrm{~cm}$ & $1.54 \pm 0.41$ & $0.73 \pm 0.52$ & $0.08 \pm 0.63$ & $2.92 \pm 3.01$ \\
\hline \multirow{2}{*}{$\mathrm{Zn}$} & $0.15 \mathrm{~cm}$ & $0.49 \pm 0.16$ & $0.43 \pm 0.18$ & $0.59 \pm 0.15$ & $1.26 \pm 0.90$ \\
\hline & $15-30 \mathrm{~cm}$ & $0.49 \pm 0.20$ & $0.35 \pm 0.13$ & $0.57 \pm 0.13$ & $0.98 \pm 0.94$ \\
\hline \multirow{2}{*}{$\mathrm{Ni}$} & $0-15 \mathrm{~cm}$ & $0.03 \pm 0.02$ & $0.02 \pm 0.01$ & $0.01 \pm 0.00$ & $0.01 \pm 0.00$ \\
\hline & $15-30 \mathrm{~cm}$ & $0.03 \pm 0.01$ & $0.02 \pm 0.01$ & $0.00 \pm 0.00$ & $0.03 \pm 0.02$ \\
\hline \multirow{2}{*}{$\mathrm{Pb}$} & $0.15 \mathrm{~cm}$ & $0.02 \pm 0.01$ & $0.02 \pm 0.01$ & $0.03 \pm 0.01$ & $0.03 \pm 0.02$ \\
\hline & $15-30 \mathrm{~cm}$ & $0.02 \pm 0.01$ & $0.02 \pm 0.01$ & $0.03 \pm 0.01$ & $0.03 \pm 0.01$ \\
\hline
\end{tabular}




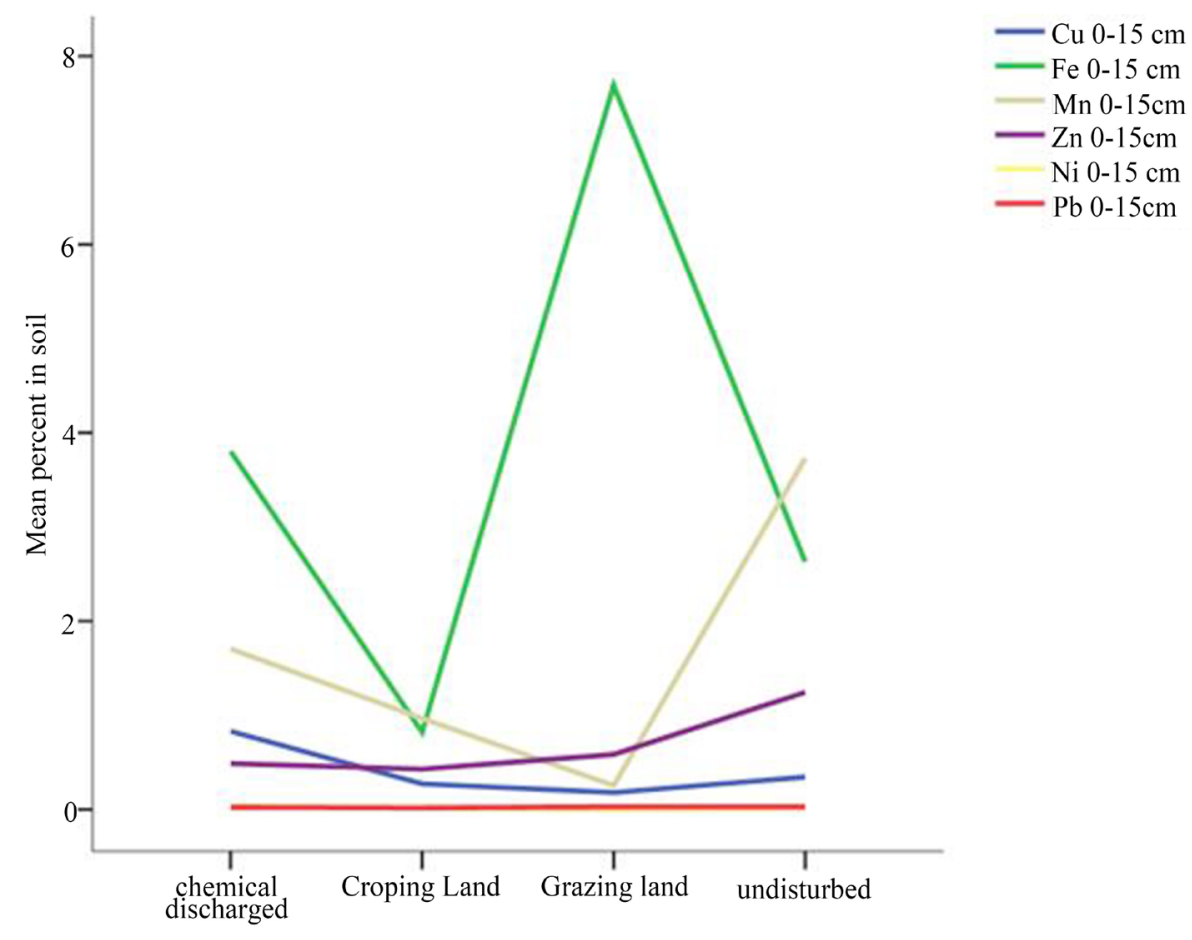

Figure 5. Micronutrients content with land use at 0 to $15 \mathrm{~cm}$ soil depth.

There was a significant difference $(\mathrm{P}<0.05)$ for $\mathrm{Cu}, \mathrm{Fe}, \mathrm{Mn}$ and $\mathrm{Zn}$ at 15 to $30 \mathrm{~cm}$ depth due to differences in ecological history. However, there was no significant difference for $\mathrm{Ni}$ and $\mathrm{Pb}$ at this soil depth. The concentration of $\mathrm{Cu}$ was significantly different between sites; chemical discharge ( $0.79 \mathrm{ppm} \pm 0.36)$, crop land $(0.17 \mathrm{ppm} \pm 0.11)$ and grazing land $(0.18 \mathrm{ppm} \pm 0.04)$, but there was no significant difference with undisturbed sites (0.58 ppm \pm 042$)$. At 15 to $30 \mathrm{~cm}$ depth the concentration of Fe was significantly different from crop land (0.77 p.m. \pm 0.92 ) and the other three ecological groups (grazing land $6.30 \mathrm{ppm} \pm 1.85$, undisturbed sites 10.30 p.m. \pm 13.22 and sites with chemical discharges $6.63 \mathrm{ppm} \pm 6.76$ ). It showed that crops absorbed a significant amount of Fe from the soil, particularly Teff for its highest iron content [41].

Mn concentration at the depth of 15 to $30 \mathrm{~cm}$ was significantly different between grazing land and the other three groups of ecological history. The highest Mn concentration was from undisturbed sites (2.92 $\mathrm{ppm} \pm 3.01)$ and the lowest was from grazing land $(0.08 \mathrm{ppm} \pm 0.63)$. Zn concentration was significantly different between the undisturbed sites and the other three ecologically different groups. There was a higher concentration of $\mathrm{Zn}$ at 15 to $30 \mathrm{~cm}$ depth for undisturbed sites $(0.98 \mathrm{ppm} \pm 0.94)$ compared with the other three ecologically different groups as shown in Table 5 and Figure 6.

Crop lands suffer from low amounts of trace elements, which calls for further investigation to see how micronutrients could be supplemented to crop lands based on crop nutrient requirements. Some crops such as Teff remove more nutrients from the soil than others. This was in agreement with the findings by other workers who reported that Teff has high micro nutrient content demands such as $\mathrm{Ca}, \mathrm{Co}, \mathrm{Zc}, \mathrm{Al}$, Se and others [31] [41].

This argument was further consolidated by findings obtained by [31] who reported that with space planting of $20 \times 20 \mathrm{~cm}$ and with the addition of NPK plus $\mathrm{Zn}, \mathrm{Cu}, \mathrm{Mn}$ and other micro-nutrients, Teff yield increased to 8.7 tons/ha, compared with the control experiment which yielded 1.5 tons/ha. This was an increase by 6 folds, in contrast with that of average yield of 1.2 tons/ha by local farms. It was also reported that under the same experimental situation straw yield has increased to 25.8 tons/ha from the traditional 3 tons/ha after the application of macro and micro-nutrient elements compared with no fertilizer application, which yielded 9 tons/ha. It was concluded that Teff varieties responded well to micronutrients supplementation particularly those that contain micro-nutrients such as $\mathrm{Zn}, \mathrm{Cu}, \mathrm{Mg}$ and $\mathrm{S}$. In general there was a higher concentration of heavy metal at 15 to $30 \mathrm{~cm}$ depth for farm lands with chemical discharged compared with the other three ecologically different groups as shown in Table 5 and Figure 6. 


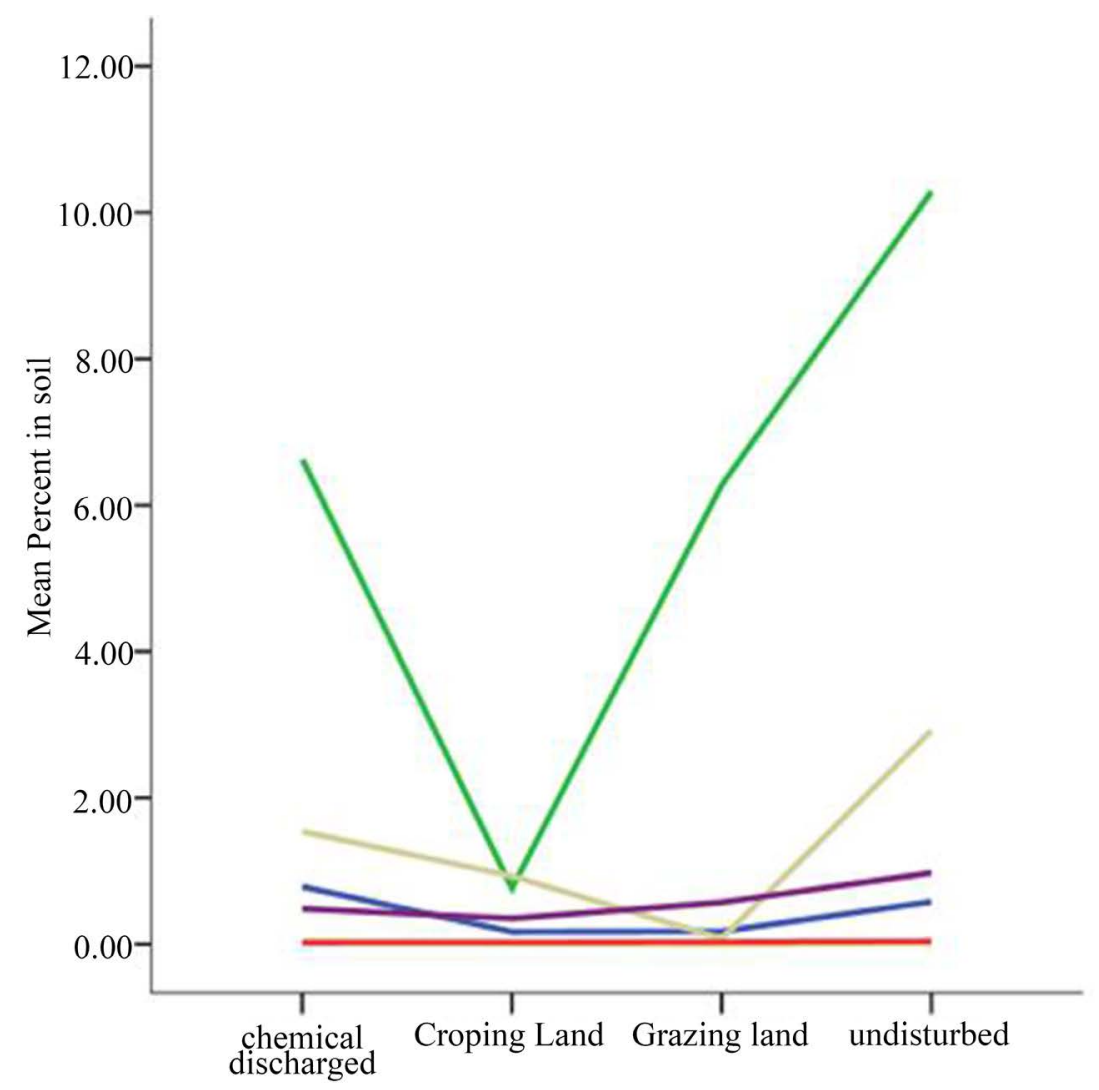

legend

- $\mathrm{Cu} 15-30 \mathrm{~cm}$

- $\mathrm{Fe} 15-30 \mathrm{~cm}$

- Mn $15-30 \mathrm{~cm}$

- Zn $15-30 \mathrm{~cm}$

Ni $15-30 \mathrm{~cm}$

$-\mathrm{Pb} 15-30 \mathrm{~cm}$

Figure 6. Micronutrients content with land use at 15 to $30 \mathrm{~cm}$ depth.

\section{Conclusions}

In terms of toxicity, the values of $\mathrm{Cu}, \mathrm{Fe}, \mathrm{Mn}, \mathrm{Zn}, \mathrm{Ni}$ and $\mathrm{Pb}$ found in the present investigation were lower than those of above critical value set by the international guidelines and other researchers. Although their impact was negligible, variability in heavy metal content was revealed mainly due to factory effluents discharge and organic sources disposal from animal products. The role of natural resources such as soil sediments, rocks and soil contents to heavy metals variability is limited.

Land use type contributed to the variability of heavy metals, particularly Fe which was very lower in cultivated soils than in an area that had never been cultivated. This showed that cereal crops like teff with higher Fe, $\mathrm{Cu}, \mathrm{Zn}, \mathrm{Mn}$ and other micro-nutrients content in their grains and straw are heavily mining these soil nutrients. However, all the available micronutrient concentrations for the central Ethiopian highland soils seem to be adequate for plant growth, but the availability of heavy metals to plants nutrition is in critical condition possibility due to higher phosphorous fertilization and lower soil organic carbon content. A report from soil scientists indicated that grain and straw yield of cereals like teff crop had over quadrupled when supplemented by micro-nutrients such as $\mathrm{Zn}, \mathrm{Cu}, \mathrm{Mg}$ and $\mathrm{S}$.

In the present study, the content of organic carbon in the soil is declining rapidly that will create further obstruction to the availability of micronutrients to plants in the future. For better crop productivity, more organic matter should be added to the soils of central Ethiopian highland. The traditional nutrient cycling practices, such as manure application, allow crop residue to decay on fields, fallow and rotational cropping has to be followed to rehabilitate the soil and buildup both macro-and micro-nutrients to their natural level.

\section{Acknowledgements}

We thank Mengistu Asfaw for payment of publication processing fee and Yasin Getahun for mapping sample sites.We gratefully acknowledge International Livestock Research Institute(ILRI) for supporting this research. 


\section{References}

[1] Yerima, B.P.K., Van Ranst, E., Sertsu, S. and Verdoodt, A. (2013) Pedogenic Impacts on the Distribution of Total and Available Fe, Mn, Cu, Zn, Cd, Pb and Co Contents of Vertisols and Vertic Inceptisols of the Bale Mountain Area of Ethiopia. African Journal of Agricultural Research (AJAR), 8, 5429-5439.

[2] Itanna, F. (1998) Comparative Study on Soil Pollution with Toxic Substances on Farm Lands Close to Old and New Industrial Sites in Ethiopia. Bulletin of the Chemical Society of Ethiopia, 12, 105-112. http://dx.doi.org/10.4314/bcse.v12i2.21049

[3] Alemayehu, T. (2001) The Impact of Uncontrolled Waste Disposal on Surface Water Quality in Addis Ababa. Ethiopian Journal of Science, 24, 93-104. http://dx.doi.org/10.4314/sinet.v24i1.18177

[4] Itanna, F. (2002) Metals in Leafy Vegetables Grown in Addis Ababa and Toxicological Implications. Ethiopian Journal of Health Development, 16, 295-302. http://dx.doi.org/10.4314/ejhd.v16i3.9797

[5] Itanna, F. and Olsson, M. (2004) Land Degradation in Addis in Ababa Due to Industrial and Urban Development. Ethiopian Journal of Developmental Research, 26, 77-100.

[6] Alemayehu, T. (2006) Heavy Metal Concentration in the Urban Environment of Addis Ababa, Ethiopia. Soil and Sediment Contamination, 15, 1-12.

[7] Hailu, A. (2007) Metal Concentration in Vegetable Grown in Northern Addis Ababa, Ethiopia. MSc Thesis, School of Graduate Study, Addis Ababa University, 79.

[8] Weldemariam, M.M. (2014) Heavy Metal (Pb, Cd, Zn, Cu, Cr and Fe) Content in Almeda Textile Industry Sludge, Northern Tigrai, Ethiopia. International Journal of Scientific and Research Publications (IJSRP), 4, No. 1.

[9] Karathanasis, A.D. and Seta, A.K. (1993) Background Levels of Heavy Metals in Some Kentucky Soils. Agricultural Experimental Station, College of Agriculture, Bull 727 Univ. of Kentucky.

[10] Esser, K.B., Bockheim, J.G. and Helme, P.A. (1991) Trace Element Distribution in Soils Formed in the Indiana Dunes. United States of America Soil Science, 152, 340-350. http://dx.doi.org/10.1097/00010694-199111000-00005

[11] Lee, B.D., Carter, B.J., Basta, N.T. and Weaver, B. (1997) Factors Influencing Heavy Metal Distribution in Six Oklahoma Benchmark Soils. Soil Science Society of America Journal, 61, 218-223. http://dx.doi.org/10.2136/sssaj1997.03615995006100010030x

[12] Kabata-Pendias, A. (2007) Trace Elements in Soils and Plants. 3rd Edition, CRC Press, Boca Raton, FL, USA.

[13] Kahsay, B. ( 2004) Land Use and Land Cover Changes in the Central Highlands of Ethiopia: The Case of Yere Mountains and Its Surroundings. M.Sc. Thesis, Addis Ababa University, 147.

[14] Minase, N.A. (2014) Assessment of Environment-Livestock Interactions in Crop-Livestock Production System of the Central Ethiopian Highland. PhD Thesis, University of South Africa, Pretoria, RSA.

[15] Tadesse, T., Haque, T. and Aduayi, E.A. (1991) Soil, Plant, Water, Fertilizer, Animal Manure and Compost Analysis Manual. ILCA PSD Working Document, B13, International Livestock Center for Africa, Addis Ababa, Ethiopia.

[16] Olsen, S.R., Cole, C.V., Watanabe, F.S. and Dean, L.A. (1954) Estimation of Available Phosphorus in Soils by Extraction with Sodium Bicarbonate. Circular/United States Department of Agriculture, No. 939.

[17] Walkley, A. and Black, I.A. (1934) An Examination of the Degtjareff Method for Determining Soil Organic Matter and a Proposed Modification of the Chromic Acid Titration Method. Soil Science, 37, 29-38. http://dx.doi.org/10.1097/00010694-193401000-00003

[18] Chapman, H.D. (1965) Cation Exchange Capacity. In: Black, C.A., Ed., Methods of Soil Analysis, American Society of Agronomy, Madison, 891-901.

[19] SPSS (Statistical Package for Social Sciences) (2008) SPSS Version 17.0.1 for Windows. SPSS Inc., USA.

[20] Everitt, B.S., Landau, S. and Leese, M. (2001) Cluster Analysis. 4th Edition, Arnold, London.

[21] Manly, B.F.J. (2005) Multivariate Statistical Methods: A Primer. 3rd Edition, Chapman and Hall, London.

[22] Zarcinas, B.A., Ishak, C.F., McLaughlin, M.J. and Cozens, G. (2004) Heavy Metals in Soils and Crops in Southeast Asia. 1. Peninsular Malaysia. Environmental Geochemistry and Health, 26, 343-357. http://dx.doi.org/10.1007/s10653-005-4669-0

[23] Alloway, B.J. (1995) Soil Processes and the Behavior of Metals. In: Alloway, B.J., Ed., Heavy Metals in Soils, Blackie Academic \& Professional, London, 38-57.

[24] Förstner, V. (1995) Riverine and Estuarine Sedimentation of Pollutants and Leaks from Sludges and Wastes: Analystical, Prognostic and Remedial Approaches. Land Degradation \& Development, 4, 281-296. http://dx.doi.org/10.1002/ldr.3400040412

[25] Rodriguez, J.A., Nanos, N., Grau, J.M., Gil, L. and Lopez-Arias, M. (2008) Multi-Scale Analysis of Heavy Metal Con- 
tents in Spanish Agricultural Top Soils. Chemosphere, 70, 1085-1096. http://dx.doi.org/10.1016/j.chemosphere.2007.07.056

[26] Cheng, S. (2007) Heavy Metal Pollution in China: Origin, Pattern and Control: A State-of-the-Art Report with Special Reference to Literature Published in Chinese Journals. Environmental Science and Pollution Research, 14, 489-489.

[27] Haque, I., Abebe, M., Mamo, T. and Dibabe, A. (1993) Nutrient Management. Improved Management of Vertisols for Sustainable Crop-Livestock Production in the Ethiopian Highlands: Synthesis Report 1986-92. Technical Committee of the Joint Vertisol Project, ILCA, Addis Ababa, 51-74.

[28] Mamo, T., Haque, I. and Kamar, C.S. (1988) Phosphorus Status of Some Ethiopian Soils. In: Jutzi, S.C., Haque, I., McIntire, J. and Stares, J.E.S., Eds., Management of Vertisols in Sub-Sharan Africa: Proceedings of a Conference Held at ILCA, Addis Ababa, Ethiopia, 31 August-4 September 1987, ILCA, Addis Ababa, 232-252.

[29] Mamo, T. and Haque, I. (1987) Phosphorus Status of Some Ethiopian Soils. I. Sorption Characteristics. Plant and Soil, 102, 261-266. http://dx.doi.org/10.1007/BF02370713

[30] Shepherd, J.G., Kleemann, R., Bahri-Esfahani, J., Hudek, L., Lalith, S.L., Elke, V.E. and van Dijk, K.C. (2016) The Future of Phosphorus in Our Hands. Nutrient Cycling in Agroecosystems, 104, 281-287

[31] Berhe, T. (2010) Increasing Productivity of Teff: New Approaches with Dramatic Results. Report, Sasakawa Africa Association, Regional Office, Addis Ababa.

[32] Chaney, R.L. and Ryan, J.A. (1993) Heavy Metals and Toxic Organic Pollutants in MSW-Compost: Research Results on Phytoavailability, Bioavailability, Fate, etc. In: Hoitink, H.A.J. and Keener, H.M., Eds., Science and Engineering of Composting Design, Environmental, Microbiological and Utilization Aspects, Renaissance Publications, Worthington, 451-506.

[33] Antoniadis, V. (1998) Heavy Metal Availability and Mobility in Sewage Sludge Treated Soils. Ph.D. Thesis, Department of Soil Science, the University of Reading, Reading, 255 p.

[34] Hamon, R.E., Lorenz, S.E., Holm, P.E., Christensen, T.H. and McGrath, S.P. (1995) Changes in Trace Metal Species and Other Components of the Rhizosphere during Growth of Radish. Plant, Cell \& Environment, 18, 749-756. http://dx.doi.org/10.1111/j.1365-3040.1995.tb00577.x

[35] Alloway, B.J. (1994) Toxic Metals in Soil-Plant Systems. John Wiley and Sons, Chichester.

[36] Williams, D.E., Vlamis, J., Pukite, A.H. and Corey, J.E. (1980) Trace Element Accumulation, Movement and Distribution in the Soil Profile from Massive Applications of Sewage Sludge. Soil Science, 129, 119-132. http://dx.doi.org/10.1097/00010694-198002000-00007

[37] Mogo, F.C. (2002) Assessment of Heavy Metals in Soil, Water, Sediments and Certain Plant Taxa in Imo and New Calabar Rivers. Ph.D. Thesis, University of Port Harcourt, Port Harcourt.

[38] Jardine, P.M., Dunnivant, F.M., Selim, H.M. and McCarthy, J.F. (1992) Comparison of Models for Describing the Transport of Dissolved Organic Carbon in Aquifer Columns. Soil Science Society of America Journal, 56, 393-401. http://dx.doi.org/10.2136/sssaj1992.03615995005600020009x

[39] Guisquiani, P.L., Gigliotti, G. and Businelli, D. (1992) Mobility of Heavy Metals in Urban Waste-Amended Soils. Journal of Environmental Quality, 21, 330-335. http://dx.doi.org/10.2134/jeq1992.00472425002100030004x

[40] He, Z.L.L., Yang, X.E. and Stoffella, P.J. (2005) Trace Elements in Agroecosystems and Impacts on the Environment. Journal of Trace Elements in Medicine and Biology, 19, 125-140. http://dx.doi.org/10.1016/j.jtemb.2005.02.010

[41] Wondimu, A. and Tekabe, F. (2001) Utilization of Teff in the Ethiopian Diet. Narrowing the Rift. Teff Research and Development: Proceedings of the International Workshop on Teff Genetics and Improvement, Debre Zeit, 16-19 October 2000, 239-244. 